\title{
Kegiatan Bimbingan Belajar dalam Meningkatkan Minat Belajar Siswa di Kelurahan Bolong Karanganyar
}

\author{
Ikrama Prasetya ${ }^{1}$, Elmira Tita Ulima ${ }^{2}$, Ira Dwi Jayanti ${ }^{3}$, Septia Gendis Pangestu ${ }^{4}$, Riska Anggraeni ${ }^{5}$, \\ Sri Arfiah ${ }^{6}$ \\ ${ }^{1,2,3,4,5,6}$ Fakultas Keguruan dan Ilmu Pendidikan, Universitas Muhamamdiyah Surakarta, Indonesia
}

\section{INFORMASI ARTIKEL}

\section{Histori Artikel:}

Submit : 12 Juni 2019

Direvisi : 21 Juni 2019

Diterima : 30 Juni 2019

Publikasi : 1 Juli 2019

\section{Kata Kunci:}

implementasi

bimbingan belajar

minat belajar

\section{Correspondent Author:}

Ikrama Prasetya

Fakultas Keguruan dan Ilmu Pendidikan

Universitas Muhammadiyah Surakarta,

Indonesia

Email:

a320150147@student.ums.ac.id

\begin{abstract}
ABSTRAK
Bimbingan Belajar sangat berperan penting bagi perkembangan belajar anak, karena tidak hanya apa yang diperoleh di sekolah saja, pembelajaran diluar sekolah mempunyai dampak yang cukup besar dan berpengaruh bagi motivasi belajar siswa. Pendidikan Non Formal diharapkan dapat menambah minat atau ketertarikan siswa dalam belajar. Didalam pendidikan non formal siswa di ajak belajar dengan metode yang berbeda dengan pendidikan formal pada umumnya, pendidikan non formal lebih santai dan atraktif dengan mengenalkan suatu hal baru atau apa yang mereka tidak paham dengan hal menarik, berbeda dengan pendidikan formal, belajar lebih menyenangkan dengan bermain game sebagai selingan dan juga sisipan dalam belajar. Siswa tidak hanya dituntut bisa menghafal tetapi juga harus paham dan tertarik, karena dengan tertarik siswa dengan sendirinya mencari tahu apa yang mereka tidak tahu. Untuk itu diterapkannya pembelajaran dengan metode belajar dan bermain sehingga dapat memotivasi siswa dalam pembelajaran agar menjadi individu yang lebih kreatif dan juga aktif dalam berfikir dan juga memecahkan masalah.
\end{abstract}

\section{Pendahuluan}

Pada prinsipnya setiap siswa memiliki hak memperoleh peluang untuk mencapai kinerja akademik yang memuaskan. Namun, dalam realita sehari-hari, setiap siswa memiliki berbagai perbedaan, baik dalam hal kemampuan intelektual bakat, minat, kemauan, perhatian, partisipasi, latar belakang keluarga, sikap, dan kebiasaan belajar yang terkadang sangat mencolok antara siswa yang satu dengan lainnya. Sementara itu, penyelenggaraan pendidikan di sekolah pada umumnya lebih ditujukan pada siswa yang berkemampuan ratarata sehingga yang berkemampuan kurang menjadi terabaikan. Siswa yang termasuk kategori di luar rata-rata (siswa yang pintar atau yang bodoh) tidak bisa memperoleh kesempatan yang memadai untuk berkembang sesuai kapasitasnya. Jadi, kesulitan belajar dapat terjadi dan dialami oleh siswa yang bodoh, yang berkemampuan rata-rata, maupun siswa yang berkemampuan tinggi.

Kondisi tersebut disebabkan oleh berbagai faktor, baik internal maupun eksternal siswa. Faktor internal mencakup kapasitas kognitif, afektif, maupun psikomotorik. Faktor eksternal meliputi lingkungan keluarga, lingkungan pergaulan teman sebaya, lingkungan 
masyarakat, lingkungan sekolah, lingkungan budaya, dan sebagainya. Atas dasar realita tersebut guru pembimbing harus bekerjasama dengan wali kelas ataupun guru matapelajaran untuk melakukan diagnosis pemecahannya melalui layanan bimbingan belajar untuk meningkatkan kualitas proses belajar-mengajar. Upaya-upaya tersebut akan ditelaah dan diperdalam melalui kajian artikel ini. Dengan upaya-upaya ini diharapkan dapat mendorong dan meningkatkan kualitas proses belajarmengajar yang berkesinambungan.

Diharapkan dengan diadakannya kegiatan bimbingan belajar di Posko KKN Kelurahan Bolong, dapat meningkatkan prestasi akademik siswa asuh sesuai dengan upaya dan kemampuan mereka masing-masing. Dengan demikian, fungsi utama dari layanan bimbingan belajar (layanan pembelajaran) adalah fungsi pemeliharaan dan pengembangan bagi siswa di sekolah.

Tujuan diadakannya peneelitian ini adalah untuk menemukan perbandingan minat belajar siswa di sekolah dengan bimbingan belajar yang telah kami terapkan di posko KKN dan untuk mengetahui sejauh mana motivasi siswa dalam belajar diluar sekolah. Dengan demikian, kami dapat mengetahui sejauh mana pengetahuan yang telah didapatkan siswa di sekolah. sehingga kegiatan bimbingan belajar kami hanya mengualang dan menambahkan materi.

\section{Metode Pelaksanaan}

Metode penelitian yang dipilih adalah studi literatur. Penelitian pada studi literatur ini berkaitan dengan menganalisis suatau permasalahan terhadap solusi berdasarkan buku atau literatur berkaitan dengan minat belajar siswa yang dihasilkan dari bimbingan belajar. Teknik analisis yang digunakan yaitu analisis SWOT. Teknik analisis SWOT memiliki 4 kegiatan utama yaitu: strengths, weaknesses, opportunities, dan threats. Dalam teknik tersebut, langkah pertama yaitu mengevaluasi kekuatan, kedua menganalisis kelemahan, ketiga menganalisis kesempatan, dan terakhir menganalisis ancaman. Tujuan dari analisis SWOT yaitu untuk mendapatkan suatu solusi yang tepat terhadap suatu permasalahan.

\section{Hasil Pelaksanaan dan Pembahasan}

Dalam upaya meningkat minat belajar siswa di era milenial, dimana siswa lebih berminat belajar dengan menggunakan hal-hal yang menarik dan santai. Maka, kami memberikan wadah untuk siswa di daerah kelurahan Bolong, Karanganyar berupa bimbingan belajar. Bimbingan belajar ini diharapkan dapat mengembangkan pengetahuan serta wawasan siswa. Beberapa upaya untuk mendukung kegiatanini adalah dengan menggunakan metode SWOT yaitu strength, weakness, opportunities, dan threats.

Pertama yaitu Strenght (Kekuatan),bimbingan belajar yang kami adakan di kelurahan Bolong, Karanganyar bertujuan untuk mengetahui sejauh mana pengetahuan yang telah siswa dapatkan di sekolah. Dan ketika bimbingan, kami hanya berusaha mengulang pelajaran tersebut, sehingga hal ini akan menuntut mereka untuk mengingat kembali pelajaran yang lalu dan membuat siswa semakin paham dengan materi tersebut.

Berdasarkan hal tersebut, bimbingan ini memiliki tujuan belajar secara umum, yaitu:

1. untuk mendapatkan pengetahuan;

2. merupakan upaya untuk menanamkan konsep dan keterampilan;

3. merupakan upaya untuk membentuk sikap dan perilaku. 
Dengan demikian, pencapaian tujuan belajar tersebut adalah sebuah usaha untuk menghasilkan (karir belajar) yang mencakup:

1. kepribadian atau sikap tentang hal ihwal pengetahuan, keilmuan, dan konsep-konsep yang bersifat kognitif;

2. hal ihwal personal bersifat afektif;

3. hal ihwal perilaku dan keterampilan yang bersifat psikomotorik.

Ketiga hal ini dalam kegiatan belajar mengajar direncanakan sesuai dengan konteks materi agar menjadi satu kesatuan yang utuh. Dengan demikian, proses internalisasi siswa dalam psikologi membutuhkan suatu sistem lingkungan belajar yang kondusif.

Kegiatan bimbingan belajar ini berlangsung kurang lebih selama satu bulan. Selama kegiatan berlangsung antusas anakanak dalam belajar semakin terlihat. Misalnya siswa datang lebih awal dari pada waktu yang telah kami tentukan sebelumnyadan rela menunggu jika kami (pembimbing) istirahat sejenak karena baru saja selesai melaksanakan kegiatan lain.

Selain itu, jarak rumah siswa dari posko KKN kami yang cukup jauh tak membuat mereka pantang menyerah menuntut ilmu bersama. Karena melihat semangat serta antusias siswa membuat kami (pembimbing) berusaha maksimal dalam memberikan pembelajaran yang tidak membosankan dan selalu menarik perhatian siswa.

Kedua yaitu Weaknesses (Kelemahan)berdasarkan karakteristik anak usia sekolah dasar dan menengah yang masih rentan untuk fokus dalam belajar ini membuat kegiatan bimbingan belajar kami menjadi sulit dikendalikan. Selain itu, pemahaman materi yang siswa dapatkan di sekolah terbilang sangat kurang. Karena masih banyak siswa yang belum memahami materi-materi dasar yang harusnya sudah mereka kuasai. Hal tersebut membuat kerja ekstra pembimbing, dalam mengulang pelajaran tersebut sehingga siswa dapat benar-benar memahami materi.

Karena memiliki berbagai faktor yang membuat kurang fokusnya siswa dalam belajar, bimbingan belajar ini kami imbangi dengan berbagai permainan dan membiarkan siswa untuk istirahat sejenak disela-sela pembelajaran berlangsung. Hal ini diharapkan dapat mengembalikan fokus dan menambah minat belajar siswa.

Ketiga yaitu Opportunities (Kesempatan), bimbingan belajar ini mengacu pada pengalaman di lapangan yang menunjukkan berbagai kesulitan, permasalahan dan bahkan kegagalankegagalan siswa yang dialami siswa dalam belajar di sekolah. Hal ini yang mengakibatkan rendahnya rasa ingin tahu serta pengetahuan yang siswa dapatkan.

Dalam satu kelas di sekolah biasanya terdapat lebih dari dua puluh siswa dengan karakteristik yang berbeda-beda. Misalnya siswa dengan sifat yang lebih suka mendengarkan dibandingkan mempraktikan atau sebaliknya atau bahkan terdapat siswa yang kurang percaya diri sehingga takut untuk mengungkapkan apa yang ingin mereka sampaikan.

Selain faktor mengenai karakteristik siswa, terdapat pula faktor-faktor yang lain, yaitu:

1. Intelegensi, yaitu kemampuan dan kecakapan siswa menghadapi dan menyesuaikan diri denga situasi yang ada secara cepat dan efektif.

2. Perhaatian, yaitu perhatian terhadap materi yang sedang dihadapi termasuk potensi yang sangat mendukung mutu proses belajar siswa. Tingkat keberhasilan siswa dalam belajar siswa tergantung pada sejauh mana konsentrasi siswa terhadap materi pelajaran. 
3. Minat, yaitu kecenderungan yang tetao untuk memperhatikan berbagai aktivitas belajar yang diminati. Bila minat siswa terbangun, maka dapat memunculkan suatu partisipasi aktif yang disertai rasa senang sehingga akan memperoleh kepuasan dalam belajar.

4. Bakat, yaitu kemampuan actual dalam belajar yang menurut Hilgard disebut "the capacity to learn". Potensi aktualiteit ini akan tampak setelah siswa belajar dan berlatih. Potensi ini sangat berarti bagi peningkatan kualitas belajar siswa di sekolah.

5. Motivasi, yaitu motor penggerak utana (terutama motivasi interinsik) bagi siswa, terutama terkait dengan tujuan yang ingin dicapai oleh setiap siswa yang belajar.

6. Kematangan, James Drever menyatakan bahwa kematangan merupajan "prepareadeiness to respond" yaitu suatu fase pertumbuhan dan perkembangan dimana anak telah memiliki readiness, baik fisik maupun psikisnya.

7. Kesiapan, kecakapan-kecakapan dalam belajar menentukan kemajuan dalam belajar yang "react" (kesiapan memberi respon) terhadap suatu materi yang disajikan.

8. Kelelahan, dalam hal belajar kelelahan fisik maupun psikis sangat berdampak negatif bagi proses pembelajaran siswa.

Beberapa faktor diataslah yang memotivasi kami untuk menciptakan bimbingan belajar yang dapat menumbuhkan minat belajar siswa serta menambah wawasan dan juga pengetahuan siswa mengenai hal-hal yang sudah maupun belum mereka pahami dan mereka dapatkan di sekolah.
Keempat yaitu Treathment (Tindakan) dalam menumbuhkan minat belajar siswa dapat diperoleh dari pengaruh internal serta eksternal. Pengaruh internal meliputi pembelajaran yang siswa dapatkan dari keluarga terutama kedua orang tua memberikan pelajaran mencakup kapasitas kognitif, afektif maupun psikomotorik. Faktor ekternal meliputi pembelajaran yang siswa dapatkan dari lingkungan teman sebaya, lingkungan masyarakat serta di lingkungan sekolah.

\section{Simpulan}

Implementasi bimbingan belajar yang kami lakukan di kelurahan Bolong, Karanganyar ini cukup memberikan nilai positif bagi siswa-siswi disana. Dengan adanya bimbingan belajar ini, siswa dapat menambah wawasan dan pengetahuan yang belum atau sudah mereka dapatkan sebelumnya. Selain itu, bimbingan belajar juga menjadi salah satu usaha kami untuk meningkatkan minat belajar siswa dengan kegiatan-kegiatan yang menarik dan tidak membosankan untuk mereka.

Dengan adanya bimbingan belajar ini dapat disimpulkan bahwa kegiatan belajar mengajar dapat berlangsung secara efesien dan efektif jika pengajar atau pembimbing mampu menciptakan suasana yang menyenangkan dan menarik perhatian siswa. Hal tersebut diharapkan mampu mengembalikan fokus siswa dalam belajar dan membuat siswa dapat memahami materi dengan mudah.

\section{Daftar Pustaka}

Abidin, Zainal. (2006). "Layanan Bimbingan Belajar sebagai Upaya Peningkatan Kualitas Proses Belajar Mengajar". Jurnal Pemikiran Alternatif Kependidikan. Vol. 11 No. 1 April 2006: 34-48. P3M STAIN Purwokerto. 
Ahmadi, Abu. 1990. Psikologi Belajar. Jakarta: Rineka Cipta.

Departemen Pendidikan dan Kebudayaan. 1992. Himpunan Peraturan PerundangUndangan Bidang Pendidikan dan Kebudayaan.

Djamarah, Saiful Bahri. 1994. Prestasi Belajar dan Kompetensi Guru. Surabaya: Usaha Nasional.

Fry, Ron. 1994. How to Study. Singapore: Published by Bussiness Tool Box.

Hallen. 2002. Bimbingan dan Konseling. Jakarta: Ciputat Press.

Hamalik, Oemar. 1992. Psikologi Belajar Mengajar. Bandung: PT. Sinar Baru.

Mudzakir, Ahmad. 1997. Psikologi Pendidikan. Bandung: Pustaka Setia.
Prayitno. 1994. Dasar-dasar Bimbingan dan Konseling. Padang: Jurusan Psikologi Pendidikan dan Bimbingan Fakultas Ilmu Pendidikan..

Sardiman. 1992. Interaksi dan Motivasi Belajar-Mengajar. Jakarta: Rajawali Pers.

Silverman, Robert. E. 1969. Psychology. New York: Appleton Century Craft Educational Devision Meredith Corporation. Slameto. 1995. Belajar dan Faktor-faktor yang Mempengaruhi. Jakarta: CV. Rineka Cipta. 